The poor sleep caused by stopping nitrazepam is a further reminder of how such drugs create conditions that lead to perpetuation of intake. Patients should be told that after giving up nitrazepam $5 \mathrm{mg}$ or similar drugs they may experience an increase in wakefulness for a week or two, with one or two nights of little sleep. They should be reassured that this disrupted sleep is a temporary consequence of their dependence on the drug that has been withdrawn and that as the weeks pass their sleep will improve again.

We thank Beecham Products Ltd for their help.

\section{References}

1 Adam, K, et al, British Medical fournal, 1976, 1, 195.

2 Sassin, J F, et al, Life Sciences, 1969, 8, part 1, 1299.

3 Schnure, J J, et al, fournal of Clinical Endocrinology and Metabolism, 1971, 33, 234.

${ }^{4}$ Ogunremi, O O, et al, British Medical fournal, 1973, 2, 202.
${ }^{5}$ Hunter, W M, Technique Radioimmunologique, (editor). G Rosselin. Paris, Centre de Recherches INSERM, Hôpital St Antoice, 1972.

${ }^{6}$ Rechtschaffen, A, and Kales, A, (editors), Manual of Standardized Terminology, Techniques and Scoring System for Sleep Stages of Human Subjects. Washington, US Government Printing Office, 1968.

${ }^{7}$ Winer, B J, Statistical Principles in Experimental Design. New York, McGraw-Hill, 1971.

${ }^{8}$ Ferguson, G A, Statistical Analysis in Psychology and Education. New York, McGraw-Hill, 1959.

${ }^{9}$ Feinberg, I, et al, Journal of Psychiatric Research, 1967, 5, 107.

${ }^{10}$ Feinberg, I, Comprehensive Psychiatry, 1968, 9, 138.

11 Williams, R L, et al, EEG of Human Sleep. New York, Wiley, 1974.

12 Błezinová, V, Electroencephalography and Clinical Neurophysiology, 1975, 39, 273.

${ }^{13}$ Dunnell, K, and Cartwright, A, Medicine Takers, Prescribers and Hoarders. London, Routledge and Kegan Paul, 1972.

${ }^{14}$ Kales, A, et al, Archives of General Psychiatry, 1970, 23, 226.

${ }^{15}$ Kales, A, et al, Archives of General Psychiatry, 1970, 23, 211.

${ }_{16}^{16}$ Oswald, I, and Priest, R G, British Medical fournal, 1965, 2, 1093.

17 Kales, A, et al, Archives of General Psychiatry, 1970, 23, 219.

18 Hartmann, E, and Cravens, J, Psychopharmacologia, 1973, 33, 233.

19 Fisher, C, et al, Archives of General Psychiatry, 1973, 28, 252.

${ }^{20}$ Allen, S, and Oswald, I, British .7ournal of Clinical Pharmacology, 1976, 3,165 .

\title{
Comparative study of short-term recovery of mental efficiency after anaesthesia
}

\author{
J E P SIMPSON, C J GLYNN, A G COX, SIMON FOLKARD
}

British Medical fournal, 1976, 1, 1560-1562

\section{Summary}

Two common general anaesthetic techniques were compared to evaluate the time taken for the patient's mental efficiency to recover sufficiently for him to be escorted home after inguinal herniorrhaphy. Recovery in performance efficiency to at least $60 \%$ of the patient's own maximum is suggested as a criterion for discharge, and this needs a stay in hospital of seven to nine hours.

\section{Introduction}

It is a long-established practice to allow some patients home within hours of receiving a short general anaesthetic for minor surgery. Recently this practice has been extended to operations for hernia and varicose veins that have longer periods of anaesthesia and an increase in operative trauma. ${ }^{1}$ We compared two common general anaesthetic techniques to evaluate the time taken for recovery sufficient to allow the patient to be escorted home. Unlike previous related studies ${ }^{2}{ }^{3}$ the time base was in hours and the investigation took account of several factors including the age of the patient, length of operation, nature of surroundings, and circadian variation in mental ability.

Northwick Park Hospital, Harrow, Middlesex HA1 3UJ

J E P SIMPSON, BM, FRCS, surgical registrar

C J GLYNN, MB, FFARCS, anaesthetic registrar

A G COX, MD, FRCSED, consultant surgeon

MRC Perceptual and Cognitive Performance Unit, University of Sussex

SIMON FOLKARD, BSC, PHD, research psychologist

\section{Patients and methods}

Thirty men were admitted on Friday evenings for unilateral inguinal herniorrhaphy. The purpose of the trial had been explained, and after specific instruction they practised the tests to be used in the study before consenting to undertake them every four hours for the next 10 days.

On the next Monday they underwent herniorrhaphy at hourly intervals from 0930 to 1230 , the operation time varying from 29 to 49 minutes (mode 35 minutes). The anaesthetic techniques are summarised in table I. Premedication and induction with thiopentone was similar for every patient, after which one group received a nitrous oxide-oxygen inhalation with fentanyl analgesia (fentanyl anaesthetic) and the other group inhaled halothane, nitrous oxide, and oxygen (halothane anaesthetic). There was no statistically significant difference between the subgroups in either age (mean 50 years; range 29-68 years) or weight (mean $72 \mathrm{~kg}$; range $49-98 \mathrm{~kg}$ ).

Three objective tests of performance efficiency were used in the trial, each reflecting a different type of ability. The tests were administered four times a day at 0800,1200,1600, and 2000, and each involved five three-minute episodes on each occasion (fig 1).

TABLE I-Anaesthetic techniques. The same technique was used throughout each list; on five mornings the anaesthetic was fentanyl and on three mornings it was halothane

Premedication one hour before surgery with papaveretum $20 \mathrm{mg}$ and hyoscine $0.4 \mathrm{mg}^{*}$

\begin{tabular}{|c|c|}
\hline "Fentanyl" ( $(n=18)$ & "Halothane" $(n=12)$ \\
\hline $\begin{array}{l}\text { Thiopentone } 250 \mathrm{mg} \\
\text { Pancuronium } 6 \mathrm{mg} \\
4^{\text {" }} \text { Lignocaine spray } \\
\text { Cuffed Magill tube } \\
\text { Mapleson D circuit } \\
\text { Manley ventilator } \\
\text { Fresh gas flow } 3 \text { litres } \mathrm{O}_{2} 6 \text { litres } \mathrm{N} . \mathrm{O} \\
\text { Tidal volume } 10 \mathrm{ml} / \mathrm{kg} \\
\text { measured with Wright Respirometer } \\
\text { Fentanyl } 0.05 \mathrm{mg}+ \\
\text { Atropine } 1.2 \mathrm{mg} \\
\text { Neostigmine } 2.5 \mathrm{mg}\end{array}$ & $\begin{array}{l}\text { Thiopentone } 250 \mathrm{mg} \\
\text { Suxamethonium } 75 \mathrm{mg} \\
4^{\circ} \text { "Lignocaine spray } \\
\text { Cuffed Magill Tube } \\
\text { Mapleson A circuit } \\
\text { Fresh gas flow } 3 \text { litres } \mathrm{O}_{2} \\
6 \text { litres N.O } \\
\text { Halothane } 1^{\prime \prime},\end{array}$ \\
\hline
\end{tabular}

*One patient whose weight was below $50 \mathrm{~kg}$ received papaveretum $15 \mathrm{mg}$ and hyoscine $0.3 \mathrm{mg}$ + Two patients required a further $0.05 \mathrm{mg}$ fentanyl for pain as judged by tachycardiac
rise in blood pressure, sweating, lacrimation, and dilatation of the pupils. 
The first and fourth episode examined the highest function, logical reasoning ability, by offering a series of sentences, each purporting to describe the order of the letters $A$ to $B$ in the letter pair that followed. The patient's task was to indicate whether the sentence was a true or false description of the letter pair. ${ }^{4}$ The second and fifth episode tested two-digit addition, while the third episode entailed searching lines of random capital letters and underlining letter pairs, triplets, or quadruplets. This search exercise was intellectually the simplest task, and provided a simultaneous test of visual acuity. In all three tests the patients were instructed to work quickly but as accurately as possible without checking their answers.

Logical reasoning test-episodes 1 and 4

\begin{tabular}{llc}
\hline & True & False \\
\hline A follows $\mathrm{B}-\mathrm{AB}$ & \\
$\mathrm{A}$ is preceded by $\mathrm{B}-\mathrm{AB}$ \\
A does not follow $\mathrm{B}-\mathrm{AB}$ \\
$\mathrm{B}$ is not preceded by $\mathrm{A}-\mathrm{AB}$ \\
$\mathrm{B}$ is followed by A-BA
\end{tabular}

Sample from 32 sentences presented in random order on 12 differing sheets.

Addition test-episodes 2 and 5

\begin{tabular}{|ccccc|}
\hline 95 & 97 & 35 & 89 & 95 \\
44 & 43 & 87 & 69 & 98 \\
61 & 81 & 31 & 96 & 82 \\
42 & 88 & 37 & 19 & 65 \\
77 & $\frac{94}{403}$ & $\underline{36}$ & $\frac{25}{298}$ & $\underline{379}$ \\
\hline
\end{tabular}

Sample from 840 sums presented on 12 differing sheets.

Cancellation of letter pairs-episode 3

KMYTBGZGMVIQBTYPKRNMLALVKKJGQR

OLLPMIJKHLLHDSTVZQLHEHJTT GKERU

PSBGWGEIMNJJSRMCOAMYLKBBXUWKTA

CGFVNSKGCEQVULIELQUVRHVOBDQOQV

UQZEFZNYSQGTHJRQOAKRMFUIAACBQF

MRIXSYYBOQXCUDONUZIUSLCWWSBIKL

ZBDLDQVGTKSDPBEJHOEHKQC $\overline{M N Z X H U Y ~}$

Sample of one out of 72 capital letters presented in 12 differing sheets.

FIG 1-The three tests of intellectual function. Each four-hourly test consisted of five episodes of three minutes each.

The question sheets were presented in different orders made up into pads of different thickness to complicate informal attempts at comparison. The patients stayed by themselves in a four-bedded ward to prevent disturbance during tests. No information was given on performance, the papers being marked after the patient's discharge from hospital. The patients acted as their own controls for level of performance, but the study was not blind or randomised.

\section{MEASURES OF PERFORMANCE}

A composite score reflecting both the speed and accuracy of the patients' performance was analysed for each test period. In all cases the patients' performance scores had reached a plateau by the Saturday after the operation. Each Saturday value was therefore taken as a standard and used as a denominator to express the scores on the day of operation as a percentage. This provided a control for the effect of time of day, which can produce a variation in performance of up to $10 \%$

Every patient's performance improved at first as they became familiar with the tests, but by the Sunday evening before operation performance efficiency was within $5 \%$ of that on the "standard" Saturday. This makes it most unlikely that the disruptive effect of the operation and anaesthetic could have been confounded by a need for further practice.

\section{Results}

At first the patients who received a gas-oxygen relaxant anaesthetic (fentanyl) recovered more quickly, all of them answering questions logically in the theatre recovery room one hour after surgery and 14 out of 18 attempting the tests at 1600 . None of the patients who received halothane anaesthesia were awake one hour after the operation, and only two responded to verbal commands; at 1600 five out of 12 patients undertook the tests. By 2000 all the patients undertook the tests, and the order was now reversed, with those who had received halothane performing significantly better.

The study was designed to enable hourly comparisons in the level of recovery from three to 10 hours after the operation. The operations took place every hour, from 0930 to 1230 . The patients operated on at 0930 were out of the theatre at about 1000 and when tested at 1600 and 2000 were, respectively, six and 10 hours from the end of their anaesthetics. Similarly the patients operated on at 1030 were five and nine hours from the end of their anaesthetics respectively when tested at 1600 and 2000 . By thus subdividing the 1600 and 2000 data we obtained an hourly record of the recovery of performance after two types of anaesthetic.

In plotting the recovery curves (fig 2 ) the percentage efficiences in the three tests were pooled to give a global index of performance, and, because each data point was based on three to five patients, the curves were smoothed by the three-point moving average technique. Up to five hours after the operation there was a slight advantage for fentanyl, mainly because most patients in this group were sufficiently awake to attempt the tests. From seven hours onwards there was an advantage for halothane, not only in performance efficiency but also in a more consistent recovery, the standard error of the mean being on average $\pm 7 \cdot 7$ after halothane and \pm 19.6 after fentanyl. At 2000 the performance efficiency of six of the patients who had received fentanyl was more than $40^{\circ}$, below their normal ; two of these patients had undergone their operations at 0930 .

Statistical significance cannot be attached to the difference between the two curves since each curve was partially a within-subjects comparison and partially a between-subjects comparison. Table II, however, shows that the 2000 results in the halothane group were significantly better than those in the fentanyl group for all three tests this time corresponds to seven to 10 hours after operation. Moreover, the fentanyl group scored significantly higher than the halothane group on the cancellation test at 1600-that is, three to six hours after operation. To determine whether this disruption of performance had been influenced by other factors we computed a correlation matrix. Variation in age, length of operation, body weight, and analgesia had little if any influence on the degree to which the patient's performance was disrupted.

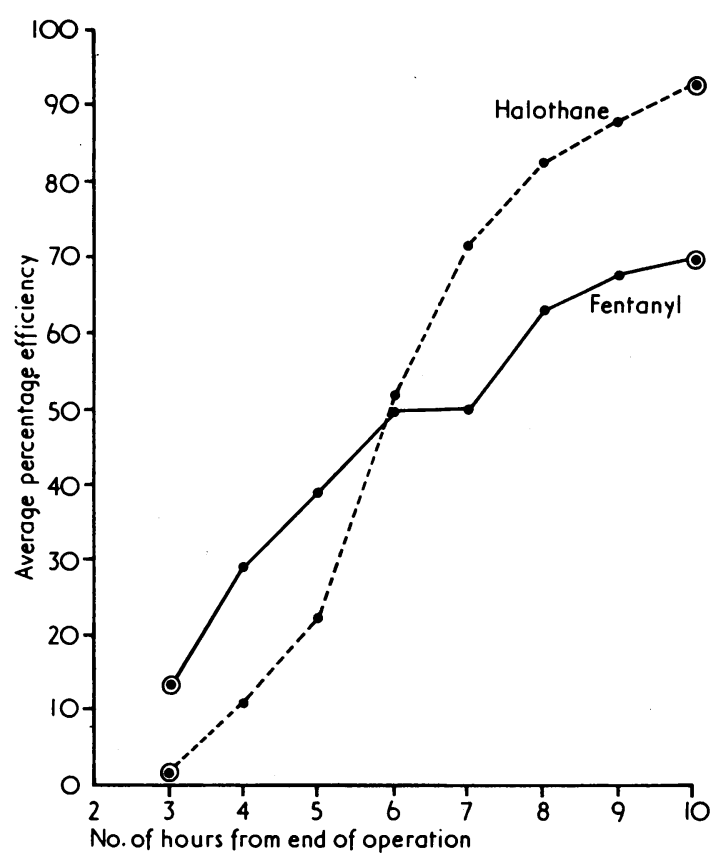

FIG 2-Short-term recovery of efficiency after the two types of anaesthesia. Data for the three performance tests were pooled. $\odot=$ Only two points contributed to these averages. 
TABLE II-Percentage efficiency relative to day 8 (Saturday)

\begin{tabular}{|c|c|c|c|c|}
\hline & & \multicolumn{2}{|c|}{ Monday } & \multirow{2}{*}{ Tuesday } \\
\hline & & 1600 & 2000 & \\
\hline \multicolumn{5}{|c|}{ Logical reasoning } \\
\hline $\begin{array}{l}\text { Fentanyl } \quad . \quad \ldots \\
\text { Halothane } \quad \ddot{a} \quad \ldots \\
\text { Advantage of halothane }\end{array}$ & $\begin{array}{l}\cdots \\
\cdots\end{array}$ & $\begin{aligned} & 34 \cdot 6^{* * *} \\
& 19 \cdot 5 * * * \\
&-15 \cdot 1\end{aligned}$ & $\begin{array}{l}68 \cdot 1^{* * *} \\
88 \cdot 3^{*} \\
20 \cdot 2^{* *}\end{array}$ & $\begin{array}{l}89 \cdot 3^{* *} \\
93 \cdot 0^{*} \\
3 \cdot 7^{*}\end{array}$ \\
\hline \multicolumn{5}{|c|}{ Calculation } \\
\hline $\begin{array}{l}\text { Fentanyl } \quad . \\
\text { Halothane } \quad . \\
\text { Advantage of halothane }\end{array}$ & $\begin{array}{l}\cdots \\
\cdots\end{array}$ & $\begin{aligned} & 27 \cdot 8^{* * *} \\
& 15 \cdot 7 * * * \\
&-12 \cdot 1\end{aligned}$ & $\begin{array}{l}58 \cdot 2^{* * *} \\
79 \cdot 6 \\
21 \cdot 4^{*}\end{array}$ & $\begin{array}{l}92 \cdot 1^{* * *} \\
93 \cdot 7^{*} \\
1 \cdot 8\end{array}$ \\
\hline \multicolumn{5}{|c|}{ Cancellation } \\
\hline $\begin{array}{l}\text { Fentanyl } \quad \ldots \\
\text { Halothane } \quad . \\
\text { Advantage of halothane }\end{array}$ & $\begin{array}{l}\cdots \\
\cdots\end{array}$ & $\begin{array}{c}36 \cdot 2 * * * \\
8 \cdot 9^{* * *} \\
-27 \cdot 3^{* *}\end{array}$ & $\begin{array}{l}73 \cdot 0^{* * *+} \\
95 \cdot 4 \\
22 \cdot 4^{*}\end{array}$ & $\begin{array}{l}94 \cdot 4^{+} \\
97 \cdot 5^{+} \\
8 \cdot 3\end{array}$ \\
\hline
\end{tabular}

†This figure is based on the results in 16 patients because two were unable to do the test because of diplopia.

†This figure is based on the results in 17 patients because one was unable to do the test because of diplopia.

Significance of $(a)$ in first two rows, disruption from 100 "., efficiency; and $(b)$ in third row, difference in disruption between the two types of anaesthesia.

$* \mathrm{P}<0.05$

$\left.\begin{array}{l}* * \mathrm{P}<0.01 \\ * * * \mathrm{P}<0.001\end{array}\right\}$ on 1 -tailed $t$ test (either related or independent).

Finally, it might be argued that premedication with papaveretum $20 \mathrm{mg}$ and hyoscine $0.4 \mathrm{mg}$ does not actually form part of a day-care anaesthetic and could have affected the patient's alertness. Comparison was possible between six patients who were given $15 \mathrm{mg}$ or $20 \mathrm{mg}$ papaveretum during the afternoon of the day of operation and those receiving no further analgesia. There was no evidence in the performance scores at 1600 or 2000 that the patients receiving papaveretum after operation were more disrupted than the rest. It therefore seems unlikely that the premedication contributed to the performance results reported.

\section{Discussion}

The curves of recovery in performance efficiency were similar for the three tasks used in this trial and they were pooled to give a global index of recovery. At first there was an advantage for the fentanyl group in that they awoke earlier, but after six hours the halothane patients were equal to them in preformance and from that point became better. At 2000 on the day of operation the advantage of halothane anaesthesia was significant for all three tasks. All the tests used were short and did not examine ability to sustain attention over a prolonged period, but, clearly, this should not be required of a patient on the day of surgery.

The question arises over what is an acceptable level of performance efficiency for discharging a patient, and here the evidence has to be indirect. Under relatively common adverse conditions people are often at about $90^{\circ}$ o of their normal efficiency; $80 \mathrm{mg}$ of alcohol per $100 \mathrm{ml}$ blood, the current legal limit, reduced steering efficiency on a simulated driving task to $89^{\circ}{ }^{\circ}$, , while normal doses of psychotropic drugs caused efficiency on complex psychomotor tasks to fall to not less than $90^{\circ},{ }^{\circ}{ }^{6}$ Limiting the duration of sleep to three hours reduced efficiency to $90^{\circ}{ }_{0}$ on a similar calculation task to the one used here. ' No sleep at all the previous night reduced efficiency to $60^{\circ}{ }_{0}$. This would suggest that $60-90^{\prime \prime}{ }_{11}$ recovery would be acceptable, and this would imply a seven to nine hour stay in hospital.

In deciding whether this could be a general rule the considerable variation in performance efficiency between individuals needs to be remembered. On the $60^{\circ}{ }_{0}$, performance efficiency criterion all 12 patients receiving halothane would have gone home at 2000, but six of the 19 receiving fentanyl would have been unfit. Unfortunately the tests described here are unsuitable for use in clinical practice because a performance ability baseline has to be established for each individual. Also more goes into the decision to discharge the patient than just the level of intellectual recovery. Nevertheless, this study emphasises again the importance of support and help at home when planning day-care surgery for the individual.

\section{References}

1 Ruckley, C V, et al, Lancet, 1973, 2, 1193.

2 Green, R, et al, Anaesthesia, 1963, 18, 189.

3 Dixon, R A, and Thornton, J A, British fournal of Anaesthesia, 1973, 45, 207.

- Folkard, S, British fournal of Psychology, 1975, 66, 1.

5 Drew, G C, Colquhoun, W P, and Long, H A, Medical Research Council Memorandum, No 38. London, HMSO, 1959.

${ }^{6}$ Klein, K E, Aerospace Medicine, 1972, 43, 1207.

7 Wilkinson, R T, Edwards, R S, and Haines, E, Psychonomic Science, 1966 , 5, 471 .
Departments of Paediatrics and Pathology, Newcastle General Hospital, Newcastle upon Tyne NE4 6BE

C R PULLAN, MB, MRCP, registrar in paediatrics

$T C$ NOBLE, FRCP, DCH, consultant paediatrician

D J SCOTT, MB, MRCPATH, consultant paediatric pathologist

$\mathrm{K}$ WISNIEWSKI, MD, senior registrar in paediatric neurology

Department of Virology, Royal Victoria Infirmary, Newcastle upon Tyne NE1 4LP

P S GARDNER, MD, DIPBACT, professor of clinical virology aemic remission on immunosuppressive treatment, were seen recently. The clinical syndromes were variable and atypical and the antibody responses unpredictable. Conventional doses of pooled immunoglobulin failed to protect the two children to whom it was given. Degeneration rather than inflammation seems to characterise the encephalopathy in immunosuppressed children infected with measles virus.

\section{Introduction}

The dangers of viral, bacterial, fungal, and protozoal infections in immunosuppressed hosts have recently been summarised ${ }^{1}$ comprehensively, but relatively few examples of fatal or lifethreatening illness due to measles infection have been recorded in such patients. ${ }^{2-4}$ During the past six months there have been two cases of measles encephalopathy and one of giant-cell 